\title{
New distributional data on the genus Phoniocercus Pocock, 1893 (Scorpiones; Bothriuridae) with the first record from Argentina
}

\author{
Andrés A. OJANGUREN-AFFILASTRO ${ }^{1}$, Jaime PIZARRO-ARAYA ${ }^{2} \&$ Richard D. SAGE ${ }^{3}$ \\ ${ }^{1}$ Museo Argentino de Ciencias Naturales "Bernardino Rivadavia", División Aracnología, Av. Ángel Gallardo \\ 470, 1405DJR Buenos Aires, Argentina. ojanguren@macn.gov.ar ${ }^{2}$ Laboratorio de Entomología Ecológica, \\ Departamento de Biología, Facultad de Ciencias, Universidad de La Serena, Casilla 599, La Serena, Chile. \\ japizarro@userena.cl ${ }^{3}$ Sociedad Naturalista Andino Patagónica (SNAP), Paso Juramento 190, $3^{\circ}$ piso, 8400 \\ Bariloche, Río Negro, Argentina. rdsage1943@gmail.com
}

\begin{abstract}
Scorpion genus Phoniocercus Pocock, 1893 (Bothriuridae) is endemic to the cold humid forests of the southwestern part of South America. Up to now the known distribution of the genus was restricted to the Valdivian forests of southern Chile. In this contribution we present the first record from Argentina and the first records from central Chile. New data about their ecology and systematics are also presented.
\end{abstract}

Key words: Scorpiones, Phoniocercus, distribution, Chile, Argentina, new records.

Resumen: Nuevos datos de distribución del género Phoniocercus Pocock, 1893 (Scorpiones; Bothriurdae) con el primer registro para Argentina. El género de escorpiones Phoniocercus Pocock, 1893 (Bothriuridae) es endémico de los bosques húmedos y fríos del sudoeste de América del Sur. Hasta ahora la distribución conocida del mismo se encontraba restringida a los bosques Valdivianos del sur de Chile. En esta contribución presentamos el primer registro de la Argentina y los primeros registros del centro de Chile. También se presentan nuevos datos sobre su ecología y sistemática.

Palabras clave: Scorpiones, Phoniocercus, distribución, Chile, Argentina, nuevos registros.

\section{INTRODUCTION}

The arthropod fauna of the Temperate Zone rain forests of southern Chile and adjacent Argentina includes a large number of endemic species. This is because the area is isolated from the rest of the South American forest fauna: by the coastal and Atacama deserts to the north, the high Andes to the northeast, and by the Patagonian steppe to the east (Roig-Juñent \& Flores, 2006; Roig-Juñent et al., 2007). This is also the case for the scorpion fauna of the area, which mostly consists of endemic genera and species that all belong to the family Bothriuridae. This family of scorpions has a Gondwanean distribution, with species in southern Africa, in Australia, and especially in South America. The endemic bothriurid genera from the Valdivian cold humid forests of southern Chile are among the most basal of the family, and are most closely related to the Australian bothriurids (Prendini, 2000, 2003). Three endemic genera of this fam- ily have been described from this forest habitat: Centromachetes Lönnberg, 1897, Phoniocercus Pocock, 1893, and Tehuankea Cekalovic, 1973 (Cekalovic, 1968, 1973; Lourenço, 2001). In addition, there are also present endemic species, and species groups, of the more widely distributed genera Bothriurus and Urophonius (San Martín \& Cekalovic, 1968a; Cekalovic, 1981; Mattoni, 2002; Ojanguren-Affilastro et al., 2010, 2011).

Until this present report, there were no records of scorpions in the Valdivian forests in adjacent Argentina, even though this area has been widely surveyed in recent years by several arachnologists. All scorpion records from Argentinean Patagonia come from the Patagonian steppe habitat, (San Martín, 1965; Maury, 1968, 1979; Ojanguren-Affilastro, 2001, 2003, 2007; Ojanguren-Affilastro \& Roig-Alsina, 2001; Acosta, 2003; Mattoni, 2007; OjangurenAffilastro \& Cheli, 2009; Ojanguren-Affilastro \& Garcia Mauro, 2010; Ojanguren-Affilastro et al., 2010). In all of these reports the animals belong 
to the genera Bothriurus, Brachistosternus, and Urophonius. This absence of forest scorpions in Argentina was actually intriguing because some areas of the Andes at this latitude are at quite low elevations, which has permitted the entrance of a limited number of the most ecologically-restricted species of the Valdivian fauna into border regions of Argentina (Forster et al., 1987; Grismado et al., 2003).

The genus Phoniocercus is one of the least studied of the family. Sporadic contributions that included mention of this genus were published in the last decade of the nineteenth century and in the first half of the twentieth century (Pocock, 1893; Kraepelin, 1894, 1899; Mello-Leitão, 1932, $1941,1943,1945)$. Three more papers about this genus appeared in the 1960s (Cekalovic, 1968, 1969; San Martin \& Cekalovic, 1968b), but since then, no new contributions on this genus have appeared. According to the existing bibliography this genus is restricted to the very humid Valdivian forests of southern Chile; however, the study of material deposited in museum collections, as well as material collected in recent campaigns by the authors, demonstrates that it has a much wider distribution than previously thought. We have found specimens of this genus almost $500 \mathrm{~km}$ north of the northernmost published records, reaching drier forests of the Valparaiso Region in central Chile. During the summer of 2011-2012, a recent survey of the Río Manso Valley, in western Río Negro Province, Argentina, conducted by the third author (RDS), three specimens of the genus Phoniocercus were collected. These are the first records for this genus from Argentina.

\section{On the identity of the Phoniocercus speci- mens}

The genus Phoniocercus currently includes only two described species, Phoniocercus pictus Pocock, 1893 and Phoniocercus sanmartini Cekalovic, 1968. But despite being such a small genus, the identity of the included species in it, is not clear. The holotype of the P. pictus is lost, and the actual type locality is unknown, because it was originally mislabeled as being from the west coast of Africa. In their redescription of this species, San Martín \& Cekalovic (1968b) created a neotype for the species from an arbitrarily chosen locality, Villarica, in the Araucania Region, Chile. Even though their redescription is very complete, and has excellent figures, the criteria used by the authors to choose the type locality, and even the species mentioned as P. pictus is not supported by any previous data, making its identity dubious. That same year Cekalovic (1968) described a new species, Phoniocercus sanmarti$n i$. Unfortunately, the diagnostic characters provided by Cekalovic to separate it from $P$. pictus do not allow a clear separation of the two species. Cekalovic separated them based on different proportions of the vesicle of the telson, and on the shape of the hemispermatophore. However, the telson of most bothriurids presents a wide range of intraspecific variation, and differs between males and females. So it is not possible to separate species using this character unless a large number of specimens of both sexes is measured separately, which was not the case in Cekalovic's contribution. Finally, the distributions of both species mentioned in their descriptions are largely overlapping. This adds more confusion to their identification, since there is no clear geographical or ecological separation between them. Up to now no modern revision has been done on this genus by any author, so we consider that it is impossible, at this moment, to assign any specimen of this genus to a well-defined species.

\section{Distributional and ecological data about the genus Phoniocercus}

According to the actual bibliographic data (Cekalovic, 1968, 1969, 1982; San Martín \& Cekalovic, 1968b), the genus Phoniocercus occurs in southern Chile, from Chiloe Island ( $\mathrm{S} 42^{\circ} 26^{\prime}$ W $73^{\circ} 45^{\prime}$ ) in the south, to the city of Concepción (S $36^{\circ} 39^{\prime}-\mathrm{W} 73^{\circ} 07^{\prime}$ ) in the north. This area occurs within the political Regions of Los Lagos, Los Ríos, Araucanía, and Bío Bío. All of these previous records are in the cold or temperate humid forests, included in the Botanical Regions of "Bosque Siempreverde y de Las Turberas", "Bosque Laurifolio", and "Bosque Caducifolio" as defined by Gajardo (1993). At these latitudes, this genus does not reach very high altitudes, with all previous records ranging from sea level to a maximum of $700 \mathrm{~m}$ asl.

\section{MATERIALS AND METHODS}

Personally collected material reported here was collected with Berlese funnel traps, or manually by ultraviolet (UV) light detection at night (using UV LEDs inserted into Maglite ${ }^{\circledR}$ 3D flashlights), or in the day time by searching under rocks, bark, and logs. Point locality records were georeferenced in the field with portable Global Positioning System devices (Garmin ${ }^{\circledR}$ GPS II Plus, Etrex, Etrex Vista and Etrex Vista C) or 
retroactively using the GeoNet Names Server (http://earth-info.nga.mil/gns/html/). A distribution map was generated using ArcMap 9.0 (@Environmental Systems Research Institute, Redlands, California), by superimposing the point locality records on a spatial dataset depicting the political boundaries and topography of Argentina and Chile. The topographic coverage (as a shaded relief) was generated using digital elevation model files ( $c a 90 \mathrm{~m}$ resolution) from the CGIAR-CSI Consortium website (http:// srtm.csi.cgiar.org/).

\section{RESULTS}

\section{New records for the genus Phoniocercus}

Locality description and additional information (as available) for the new records of Phoniocercus scorpions.

\section{ARGENTINA}

Río Negro province. Canyon of the Manso river, $5 \mathrm{~km}$ E. from the border with Chile, $\mathrm{S} 41^{\circ}$ $32^{\prime} 37.92^{\prime \prime}$ - W 71 47' 33.12" 6-XII-2011, Sage coll. 1 ㅇ (MACN-Ar); 16-III-2012, Sage col. 2 ㅇ (MACN-Ar).

\section{CHILE}

Valparaíso region. Petorca province. Cuesta El Melón, 23 km S. from La Ligua, 25-X-1988, Maury coll. 1 (MACN-Ar). Quillota province. Cuesta El Melón, $17.7 \mathrm{~km}$ S. from La Ligua, S $32^{\circ} 41^{\prime} 17.66$ ” - W 71 ${ }^{\circ} 12^{\prime} 33.67$ " (GPS, $\pm 100 \mathrm{~m}$ ), $578 \mathrm{~m}$ asl, 3-XI-2011, Ramírez, OjangurenAffilastro, Pizarro, Barriga Tuñón, Rothman Toro \& Valdivia coll. 1 \& (MACN-Ar). San Felipe de Aconcagua province. Ensenada, 24-IX-1968, Núñez coll. 1 ㅇ (MACN-Ar); 24-IX1968, González coll. 1 ㅇ (MACN-Ar); 26-XI-1992, Pereira coll. 1 ㅇ (MACN-Ar). Valparaíso province. Quebrada el Tigre, Cachagua, 8-XI-1988, Maury coll. 2 juveniles; 14-XI-1987, Maury coll. 2 오 (MACN-Ar).

Maule region. Curicó province. $20 \mathrm{~km}$ E. from Potrero Grande, Fundo el Coihue, Curicó, (Fogging in Nothofagus dombeyi) (937 m asl), S $35^{\circ} 12^{\prime} 18.91^{\prime \prime}$ - W 71 ${ }^{\circ}$ ' $^{\prime} 36.73^{\prime \prime}$, 25-V-2004, Barriga coll. 1 (MACN-Ar); Los Queñes, Curicó, S $35^{\circ}$ $01^{\prime} 00^{\prime \prime}$ - W 70 48'00", 16-II-2005, Ramírez \& Labarque coll. 1 ô (MACN-Ar).

Bío Bío region. Concepción province. Reserva Hualpén, Concepción, S $36^{\circ} 47^{\prime} 51.2^{\prime \prime}$ - W $73^{\circ} 09^{\prime}$ 29.3", 16-VII-2010, Ojanguren-Affilastro,
Pizarro, Piacentini, Valdivia \& Soto coll. 3 ㅇ, 3 juveniles (U.V. collection at night, and manual collection under logs and bark in day time) (MACNAr); Cerro Caracol, Concepción, 15-II-2005, S $36^{\circ}$ $50^{\prime} 37.1^{\prime \prime}$ - W 73² $2^{\prime} 17.6^{\prime \prime}, 240 \mathrm{~m}$ asl, Ramírez \& Labarque coll. (Berlese) 1 juvenile (MACN-Ar). Arauco province. $18 \mathrm{~km} \mathrm{~N}$. from Tres Pinos, Arauco, 12-I-1987, S $37^{\circ} 39^{\prime} 0^{\prime \prime}$ - W $73^{\circ} 25^{\prime}$ 0", Maury coll. 2 (MACN-Ar).

La Araucania region. Cautín province. Calligue, Lautaro, Vellard coll. 3 ㅇ (MACN-Ar); Cerro Nielol, Maury coll. 21-I-1991, 1 juvenile (MACN-Ar); Ojos del Caburgua, $15 \mathrm{~km} \mathrm{NE}$. from Pucón, Cautín, 16-I-1987. Maury coll. 2 + , 1 juvenile (MACN-Ar); Ojos del Caburgua, $25 \mathrm{~km} \mathrm{E.}$ from Pucón, 15-I-1987, Roig coll. 1 ㅇ (MACN$\mathrm{Ar})$. Malleco province. Monumento Natural Contulmo, S $38^{\circ} 00^{\prime} 46.8^{\prime \prime}$ - W $73^{\circ} 11^{\prime} 15.4^{\prime \prime}, 360$ $\mathrm{m}$ asl, 10-II-2005, Labarque \& Ramírez coll. (Berlese) 4 ठิ (MACN-Ar); 10-I-1987, Maury coll. 2 으 (MACN-Ar); 16-XII-1985, Maury coll. 1 ㅇ MACN-Ar.

Los Lagos region. Valdivia province. Llancacura, 12-I-1966, Silva coll. 1 ㅇ (MACN-Ar); Niebla, 14-VII-1985, Maury coll. 3 ㅇ (MACN-Ar); Camping La Herradura, $15 \mathrm{~km}$ E. from Niebla, I-1991, Maury coll. 1 juvenile (MACN-Ar); Mehuín, 6-XII-1966, Castro \& Zuleta coll. 2 ㅇ (MACN-Ar); Corral, 16-I-1989, Maury coll. 1 juvenile (MACN-Ar). Osorno province. Puyehue, 20-VIII-1964, 1 q (MACN-Ar); Puyehue National Park, Sector Anticura, Sendero de Chile, S $39^{\circ}$ 44' 08.2" - W 71 40' 13.0" (WGS84), 10-XII-2010, Ojanguren, Piacentinii \& Soto coll. 2 ㅇ, 1 juvenile (MACN-Ar); Los Derrumbes, $6 \mathrm{~km} \mathrm{~S}$. from Termas de Puyehue, 8-I-1989, Maury coll. 1 juvenile (MACN-Ar); Los Derrumbes, $5 \mathrm{~km}$ S. from Termas de Puyehue, 4-XII-1985, Maury coll. 1 juvenile (MACN-Ar); Lago Rapunco, 25-IX-1968, Ortiz coll. 1 (MACN-Ar); Anticura, 9-I-1988, Maury coll. 1 juvenile (MACN-Ar); $5 \mathrm{~km}$ from Bahía Mansa, 26-IX-1968, Lang. coll. 1 q (MACN$\mathrm{Ar}) ; 5 \mathrm{~km}$ S. from Pucatrihue; Osorno, 20-I-1986, Maury coll. $1 \circlearrowleft$ (MACN-Ar). Llanquihue province. Petrohué, 9-II-1968, Solervicens coll. 1 ㅇ, 2 juveniles (MACN-Ar); Frutillar, 12-II-1966, Silva coll. 2 ㅇ (MACN-Ar); Caleta La Arena, 50 km S. from Puerto Montt, Carretera austral, 7-XII1985, Maury coll. 1 ( (MACN-Ar); Puerto Montt, 26-II-1966, 1 ㅇ (MACN-Ar). Chiloé province. Isla Chiloé, cross road to Caulín, $7 \mathrm{~km}$ S. from Chacao, 24-II-1972, Cekalovic coll. $1 \hat{\jmath}$ (MACNAr); El Quilar, 29-IX-1968, Vásquez coll. 1 ㅇ 


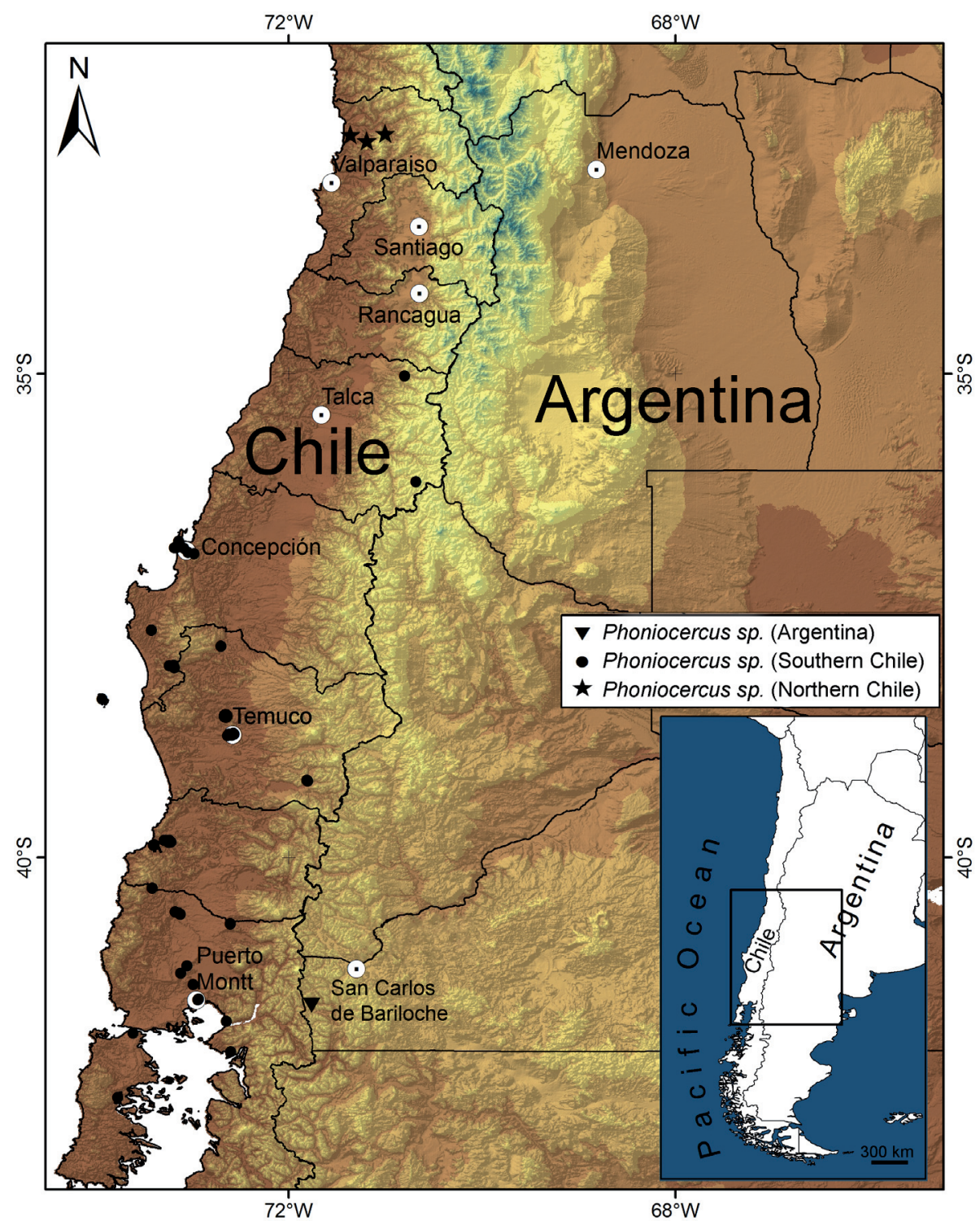

Fig. 1. Map showing the known localities of Phoniocercus sp.

(MACN-Ar); Chonchi, 2-XII-1966, Moreau coll. 2 i (MACN-Ar). Palena province. Termas de Pichicolo, $11 \mathrm{~km}$ W from Río Negro, Carretera Austral, 9-XI-1985, Maury coll. 2 +, 1 juvenile (MACN-Ar).

\section{DISCUSSION}

\section{First records from Argentina}

One of the authors (RDS) collected three specimens from Argentina that are now deposited in the MACN-Ar collection. One animal was collected on 6 December, 2011 and the other two were collected on 16 March, 2012, all near to the Manso river, in Río Negro Province, about $5 \mathrm{~km}$ west of the border with Chile (Fig. 1). The general habitat where they were found is along the southern side of Ruta 83. The collecting site (S $41^{\circ} 32^{\prime} 37.92^{\prime \prime}$ - W $71^{\circ} 47^{\prime} 33.12^{\prime \prime}$ ) is along the base of a north-facing, steep granite cliff that forms the southern edge of the road, at about $450 \mathrm{~m}$ asl. The cliff then descends to the Manso river, approximately 60 meters downhill from the other side of the road. The soil is reddish brown in color and contains very little organic matter. The surface of the ground here mainly consists of a loose 


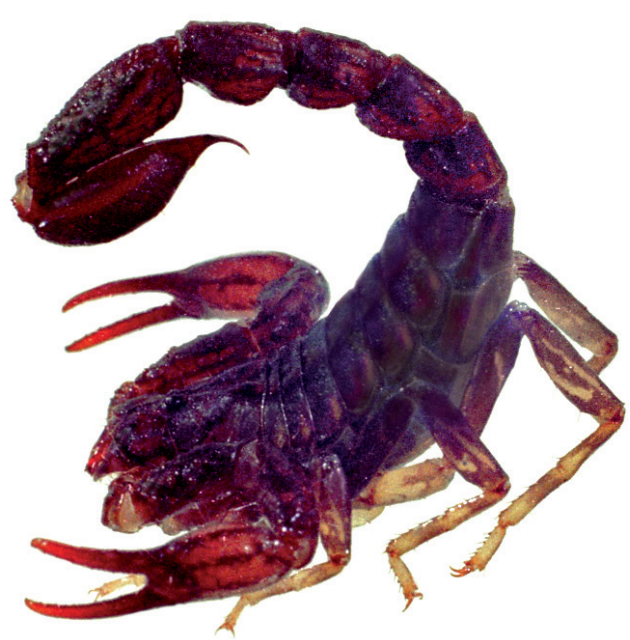

Fig. 2. Phoniocercus sp. from Argentina, living specimen in a defensive posture (Photo by R. D. Sage).

mixture of the soil and the fallen rocks. Only a sparse cover of grasses and annual herbs grew out of this rock rubble and poor soil. This steep hillside and roadway has full exposure to sunlight, and spans a distance of about one hundred meters. This open area exists between flatter stretches where there are well-developed forests, with Coihue (Nothofagus dombeyi (Mirb.) Oerst as the dominant tree. Caña Colihue (Chusquea culeou Étienne-Émile Desvaux), Arrayán Macho (Rhaphithamnus spinosus (Juss.) Moldenke), and Chilco (Fuchsia magellanica Lam.) form the dominant understory vegetation. Two of the scorpions were collected under rocks of $40 \mathrm{~cm}$ in diameter, and one from under a piece of dead tree trunk $1.5 \mathrm{~m}$ in length. In all three cases the animals were resting on the mineral soil, under the rock or wood. There was no elaborated, or excavated, tunnel leading from the resting place of the animal to the outside.

All three specimens of Phoniocercus from Argentina were collected in a humid-forest region belonging to the Subantartica Phytogeographic Province as defined by Cabrera \& Willink (1980).

These Argentinean specimens of Phoniocercus (Fig. 2) are morphologically similar to the specimens of the genus that we have studied from the same latitude in Chile, and most probably belong to that same species.

\section{New records from Chile}

We have had access to several new records of Phoniocercus that allow us to extend the known distribution of the genus to the Valparaiso Region
(Fig. 1). One of the northernmost records for the genus is one female collected by us in "Cuesta El Melón", 17.7 km S from La Ligua, in Quillota Province, S $32^{\circ} 41^{\prime} 17.66$ ” - W 71¹2' 33.67”, 578 $\mathrm{m}$ asl, on 3 November 2011. This specimen was collected in a ravine in a relictual forest, under a rock along the edge of an internal path on private property. This area belongs to the Botanical Region of "Bosque Caducifolio" as defined by Gajardo (1993). There are several other records from this area that confirm the presence of the genus at this latitude (see the list of new records above). These records are almost $500 \mathrm{~km}$ further north than the previous records from Concepción (Bío Bío Region). Northern specimens are not as pigmented as southern specimens, and most probably do not belong to the same species as the southern populations.

Specimens from intermediate localities are scarce but we have had access to specimens from Potrero Grande and Los Queñes, both in Curicó Province (Maule Region). These records are about $250 \mathrm{~km}$ from Concepción, just about one half of the distance between the new northernmost records and the earlier localities. These intermediate localities are also located in the "Bosque Caducifolio" Botanical Region.

\section{CONCLUSIONS}

\section{Biogeographical implications of these new records}

Records from Argentina. The Patagonian, cold humid forests in Argentina are in general not as rich in their arthropod faunas as their Chilean counterparts. This is probably because they are less humid and generally at higher elevations. However, most orders that include endemic species and genera in Chilean forests have some representatives in Argentinean forests. This is especially true in the most humid and temperate places, such as the area near Puerto Blest along the western border of Río Negro and Neuquén provinces. But this is not the case for scorpions, which until this report, were apparently absent from all cold forests in Argentina.

Our records of Phoniocercus from the area near the Manso river are notable mostly because of the absence of previous records of the genus in Argentina. We suspect that this is probably because this is one of only a few places that allow the passage of this genus through the Andes without having to traverse higher elevation, nonforested habitats. The canyon of the Río Manso is the northernmost place where the Andes are 
so low that there is access to the Pacific slopes at elevations below $500 \mathrm{~m}$ asl. It appears that Phoniocercus scorpions cannot live at altitudes above $600-700 \mathrm{~m}$ asl at this latitude. To the north of here nearly all passes between Chile and Argentina are above 1000 meters in elevation, and the forests in these areas may simply be too high (and too cold) for Phoniocercus to live. One notable exception is the Pirehueico (Chile) - Hua Hum-Lacar (Argentina) river system that drains into the Pacific Ocean at latitude $40^{\circ} \mathrm{S}$. At the Argentina-Chilean international boundary the river elevation is about $670 \mathrm{~m}$ asl., close to the upper elevational occurrences of Phoniocercus in this part of Chile. This part of Argentina may also harbor populations of this genus. To the south of $42^{\circ} \mathrm{S}$ latitude, where there are other low-elevation river systems (and associated valleys) shared by both countries, Phoniocercus is not present in Chile (or at least it has not yet been recorded).

What is more difficult to explain is why this genus has not spread from this entrance point to other areas of the Argentinean cold humid forests. We have three hypotheses to explain this. The Río Manso valley in Argentina is surrounded by mountains of more than $1000 \mathrm{~m}$ asl that on their eastern flanks contact the Patagonian steppe habitat. It is possible that Phoniocercus simply cannot reach suitable forests because of these mountains and the encroaching steppe habitat. Another possibility is that even if it can reach the surrounding forests adjacent to the Río Manso canyon, the environments are not optimal for this genus, thus making its presence in the area scarce and, consequently, difficult to find. Finally, it is also possible that this area has simply not been surveyed enough by specialists, thereby underestimating the actual scorpion richness of the area. More collections in all of this area will be necessary to evaluate these different hypotheses.

Records from central Chile. The presence of arachnids of the Valdivian humid forests in the northern and drier forest of central Chile has been recorded previously (Forster et al., 1987; Grismado et al., 2003). However, records of Phoniocercus from northern areas are actually very scarce, even though this area has been intensely surveyed in the last decades. It seems that in central Chile Phoniocercus is restricted to the most humid forests of the area, which are indeed very scarce. In the last ten years we have intensively surveyed the extensive and well- preserved woods of La Campana National Park in central Chile, without finding any specimen of this genus. We presume that these forests, belonging to the "Matorral y Bosque Esclerofilo" Botanical Region (Gajardo, 1993), are too dry to support populations of this genus.

One of the specimens mentioned in this contribution, from the area of Curicó, was collected while 'fogging' in a Nothofagus tree. This capture confirms that this genus spends part of its life in trees. We have previously recorded resting specimens of this genus under the bark of Peumo trees (Cryptocarya alba (Molina) Looser.) and Willow (Salix sp.), at about $2 \mathrm{~m}$ from the ground, in the Hualpén Reserve, near Concepción (Pizarro-Araya et al., 2011). However, we still do not know if this species only uses these trees as a retreat during the day, when it is not active, or if they actually live and hunt in them as does Urophonius tumbensis Cekalovic, 1981. In the Hualpén Reserve, where we have collected some inactive specimens under the bark of trees, we have also collected several active specimens of this genus on the ground at night using a UV light. We have also captured several inactive specimens on the ground, under logs, rocks, and even in leaf litter (with Berlese traps). But no active specimens have been observed in the trees.

One of the newly-examined specimens from Curicó Province, was collected at an altitude of more than $900 \mathrm{~m}$ asl, while all previously known southern records never exceeded $700 \mathrm{~m}$ asl. Most probably this is because the more temperate conditions at this latitude $\left(35^{\circ} \mathrm{S}\right)$ allow this genus to live at higher altitudes.

The presence of Phoniocercus at latitudes as far north as Valparaiso raises another problem with regards to the identity of $P$. pictus. The type material of this species is lost and the type locality is unknown. San Martin \& Cekalovic (1968b) arbitrarily decided to redescribe as $P$. pictus an entity of the genus from southern Chile. They chose a specimen from the locality of Villarica as the neotype, because this city was in the geographic center of its distribution. They based this decision on the material available in their collections at that moment, which were all animals from southern populations of the genus. However, it should be taken into account that the actual type specimen of the species was collected in the second half of the nineteenth century, when most travelers and collectors of that period usually visited and collected material in the areas around the few, developed cities of that time. So we consider that it is possible that 
the type specimen of $P$. pictus was actually collected in the highly populated area of SantiagoValparaiso, rather than in the southern, and less populated, part of the country.

\section{ACKNOWLEDGMENTS}

We would like to thank to Juan Enrique Barriga Tunón for providing the scorpion collected by fogging in southern Chile, Iván Benoit and all the personnel of CONAF (Chile) that helped us in our projects, and to the personnel of APN from Argentina for providing the permits to collect material in previous campaigns to the National Parks of Argentinean Patagonia. We also thank M. Ramírez, J. Mondaca, S. Rothman Toro, F. Alfaro Kong, L. Piacentini, E. Soto, D. Valdivia Huerta, J. E, Barriga Tuñón, J.J. Martínez, and L. Compagnucci for their help in our collecting campaigns in southern Chile and southern Argentina. Funding for the different trips and equipment used for this project was provided by PICT 2007-1393, PIP 6502, Idea Wild, MACN, and UBACyT 01/1240 (Universidad de Buenos Aires) to AAOA, and DIULS PR13121 and VACDDI001 (Universidad de La Serena), La Serena, Chile to JPA. We also thank Camilo Mattoni and Jose Ochoa for their helpful comments and suggestions.

\section{BIBLIOGRAPHY}

Acosta, L.E. 2003. Description of a new Patagonian species of Urophonius Pocock (Scorpiones, Bothriuridae), from Meseta de Somuncurá, Argentina. Zootaxa 187: 1-12.

Cabrera, A.L., \& A. Willink. 1980. Biogeografía de América Latina. Secretaría General de la Organización de los Estados Americanos (OEA), Departamento de Asuntos Científicos y Tecnológicos, Monografía 13 (Serie de Biología). $122 \mathrm{pp}$.

Cekalovic, T. 1968. Phoniocercus sanmartini nueva especie de Bothriuridae de Chile (ScorpionidaBothriuridae). Boletín de la Sociedad de Biología de Concepción 40: 63-79.

Cekalovic, T. 1969. Presencia de Phoniocercus sanmartini Cekalovic 1968 en la Isla de Chiloé y otras localidades chilenas. Boletín de la Sociedad de Biología de Concepción 49: 89-91.

Cekalovic, T. 1973. Tehuankea moyanoi n. gen. y n. sp. de escorpión chileno (Scorpiones-Bothriuridae). Boletín de la Sociedad de Biología de Concepción 46: 41-51.

Cekalovic, T. 1981. Dos nuevas especies y un nuevo registro del género Urophonius para Chile (Scorpiones, Bothriuridae). Boletín de la Sociedad de Biología de Concepción 52: 195-201.
Cekalovic, T. 1982. Los escorpiones de la Isla Mocha, Chile con la descripción de una nueva especie (Scorpiones, Bothriuridae). Boletín de la Sociedad de Biología de Concepción 53: 41-46.

Forster R., N.I. Platnick \& M. Gray. 1987. A review of the spiders superfamilies Hypochiloidea and Austrochiloidea (Araneae, Araneomorpha). Bulletin of the American Museum of Natural History 185: 1-116.

Gajardo, R. 1993. La Vegetación Natural de Chile, Clasificación y Distribución Geográfica. Editorial Universitaria, Santiago, Chile. 165 pp.

Grismado C.J., L. Lopardo \& N.I. Platnick. 2003. A new species of Austrochilus from Chile (Araneae, Austrochilidae, Austrochilinae). Journal of Arachnology 31: 148-150.

Kraepelin, K. 1894. Revision der Skorpione II. Scorpionidae und Bothriuridae. Mitteilungen aus dem Museum Hamburg 11: 234-236.

Kraepelin, K. 1899. Scorpiones und Pedipalpi. Das Tierreich 8: 1-265.

Lourenço, W. 2001. On the taxonomy and geographic distribution of the genus Centromachetes Lönnberg, 1897, with a redescription of Centromachetes pocockii (Kraepelin, 1894) (Scorpiones, Bothriuridae). Entomologische Mitteilungen aus dem zoologischen Museum Hamburg 13: 305-313.

Mattoni, C.I. 2002. La verdadera identidad de Bothriurus vittatus (Guérin-Méneville, 1838) (Scorpiones, Bothriuridae). Revue Arachnologique 14: 59-72.

Mattoni, C.I. 2007. The Bothriurus scorpions (Scorpiones, Bothriuridae) from Patagonia. Insect Systematics \& Evolution 38: 173-192.

Maury, E.A. 1968. Aportes al conocimiento de los escorpiones de la República Argentina. II. Algunas consideraciones sobre el género Bothriurus en la Patagonia y Tierra del Fuego con la descripción de una nueva especie (Bothriuridae). Physis, Sec. C 28 76: 149-164.

Maury, E.A. 1979. Escorpiofauna patagónica. II. Urophonius granulatus Pocock 1898(Bothriuridae). Physis, Sec. C 38: 57-68.

Mello-Leitão, C. de 1932. Notas sôbre escorpiões SulAmericanos. Arquivos do Museu Nacional 34: 9-46.

Mello-Leitão, C. de 1941. Arácnidos de Maullín. Revista Chilena de Historia Natural 45: 136-143.

Mello-Leitão, C. de 1943. Los Alacranes y la zoogeografía de Sudamérica. Revista Argentina de Zoología 2: 125-131.

Mello-Leitão, C. de 1945. Escorpioes Sulamericanos. Arquivos do Museu Nacional 40: 21-203.

Ojanguren-Affilastro, A.A. 2001. Sistemática y distribución de Brachistosternus alienus Lönnberg (Scorpiones, Bothriuridae). Revista del Museo Argentino de Ciencias Naturales 3: 169-174.

Ojanguren-Affilastro, A.A. 2003. The genus Brachistosternus in Argentina, with the description of a new species from Patagonia (Scorpiones, Bothriuridae). Journal of Arachnology 31: 317331. 
Ojanguren-Affilastro, A.A. 2007. A new endemic scorpion species from the Somuncura Plateau, in northern Patagonia (Scorpiones; Bothriuridae). Zootaxa 1466: 47-56.

Ojanguren-Affilastro, A.A. \& G. Cheli. 2009. New data on genus Urophonius Pocock 1893 in Patagonia, with a description of a new species of the exochus group (Scorpiones; Bothriuridae). Journal of Arachnology 37: 346-356.

Ojanguren-Affilastro, A.A. \& I. García-Mauro. 2010. A new Bothriurus (Scorpiones; Bothriuridae) from the Somuncura Plateau, with additions to the knowledge of the endemic scorpion fauna of the area. Zootaxa 2488: 52-64.

Ojanguren-Affilastro, A.A. \& A. Roig-Alsina. 2001. Brachistosternus angustimanus, una nueva especie del norte de la Patagonia, Argentina (Scorpiones, Bothriuridae). Physis Secc. C, 58 (134-135): 15-22.

Ojanguren-Affilastro, A.A., J.A. Ochoa, C.I. Mattoni \& L. Prendini. 2010. Systematic revision of the granulatus group of Urophonius Pocock, 1893 (Scorpiones, Bothriuridae), with description of a new species from central Chile. American Museum Novitates 3695: 1-40.

Ojanguren-Affilastro, A.A., J. Pizarro-Araya \& L. Prendini. 2011. New data on Chilean Urophonius (Scorpiones, Bothriuridae). American Museum Novitates 3725: 1-44.

Pizarro-Araya J., A.A. Ojanguren-Affilastro \& L. Prendini. 2011. First report of an arboreal scorpion (Bothriuridae: Urophonius) from the temperate forests of southern Chile. Gayana, 75: 166-170.

Pocock, R.I. 1893. A contribution to the study of Neotropical scorpions. Annals and Magazine of
Natural History 12: 77-103.

Prendini, L. 2000. Phylogeny and classification of the superfamily Scorpionoidea Latreille 1802 (Chelicerata, Scorpiones): An exemplar approach. Cladistics 16: 1-78.

Prendini, L. 2003. A new genus and species of bothriurid scorpion from the Brandberg Massif, Namibia, with a reanalysis of bothriurid phylogeny and a discussion of the phylogenetic position of Lisposoma Lawrence. Systematic Entomology 28: 149-172.

Roig-Juñent, S. \& G.E. Flores. 2006. Historia biogeográfica de las áreas áridas de América del Sur Austral. En: J. Llorente Busquets \& J.J. Morrone (Eds.). Introducción a la biogeografía en Latinoamérica: teorías, conceptos, métodos y aplicaciones. Las prensas de Ciencias, Facultad de Ciencias, UNAM, México, Distrito Federal, pp. 257-266.

Roig-Juñent, S., M.C. Domínguez, G.E. Flores \& C.I. Mattoni. 2007. Biogeographic history of South American arid lands: A view from its arthropods using TASS analysis. Journal of Arid Environments 66: 404-420.

San Martín, P.R. 1965. Escorpiofauna Argentina. I. Bothriuridae. Redescripción del holotipo y descripción del alotipo hembra de Urophonius eugenicus (Mello-Leitão, 1931). Physis, Sec. C 25: 283-290.

San Martín, P.R., \& T. Cekalovic. 1968a. Escorpiofauna Chilena. I. Bothriuridae. Una nueva especie de Urophonius para Chile. Investigaciones Zoológicas Chilenas 13: 81-100.

San Martín, P.R. \& T. Cekalovic. 1968b. Escorpiofauna Chilena. II. Bothriuridae. Redescripción de Phoniocercus pictus, Pocock 1893. Revista de la Sociedad Uruguaya de Entomología 7: 80-96. 